\title{
THE ECONOMIC DIMENSION OF THE ACTIVITY OF WOMEN IN THE COUNCIL OF MINISTERS IN POLAND BETWEEN 1989 AND 2008
}

\author{
by Małgorzata Kamola-Cieślik
}

Polish economy is one of but many issues with which the Council of Ministers is concerned. It is managed and run by appropriate ministries, which are responsible for how well they function.

Since 1945 most governmental jobs were given to men'. There were very few women actively functioning in public life. Throughout the history of the Polish People's Republic not a single woman was appointed either Prime Minister or VicePrime Minister and very few women were nominated as ministers. There were only two women who were responsible for economic matters, if only to a very limited degree - Maria Milczarek, the Minister of Administration, Infrastructure Economy and Environmental Protection (from $2^{\text {nd }}$ Dec, 1976 to $8^{\text {th }}$ Feb, 1979), and Anna Kędzierska - the Minister of Domestic Trade and Services (from 30 ${ }^{\text {th }}$ May, 1984 to $6^{\text {th }}$ Nov, 1985).

The political transformation which took place in Poland in the late 1980s did not have any significant effect on the role of women in Polish political life'2. Until 1997, the proportion of women holding governmental jobs was similar to that before 1989 . It was only when Jerzy Buzek was nominated as the Prime Minister that five women were appointed ministers. The successive Prime Ministers - Kazimierz Marcinkie-

1 T. Mołdawa, Ludzie władzy 1944-1991. Władze państwowe i polityczne Polski według stanu na dzień 28 II 1991 r., Warszawa, 1991, p. 167-215.

2 M. Fuszara, Kobiety w polityce, Warszawa 2007, p. 93. 
wicz, Jarosław Kaczyński and Donald Tusk - also appointed women to ministerial positions.

Between 1989 and 2008, women, although to a lesser degree than men, held governmental jobs serving the functions of the Prime Minister, Vice PM and ministers. Some of them made decisions affecting the economic situation of Poland. The decision taking process was a consequence of the functions held by them ${ }^{3}$. These positions included:

1. The President of the Council of Ministers (which in Poland is traditionally known as the Prime Minister). Hanna Suchocka was the only woman who, as PM, presided over the Council of Ministers. In 1969 she joined SD (Democratic Party) and then she started work at the Institute of Small-Scale Industry and Crafts where she also received her training as a legal advisor ${ }^{4}$. In 1972, she became a scientific worker in the Chair of Constitutional Law at Adam Mickiewicz University of Poznan. She specialized in the fields of human rights, public law and ethnic minorities. She deepened her knowledge on these topics by taking part in an American law course in Leiden, which was organized by Columbia University. She did her scientific traineeships at the Institute of Human Rights in Strasbourg and the Institute of Public Law in Heidelberg. In 1980, H. Suchocka became an MP representing the Democratic Party. Also in 1980, she became a member and expert of the Independent and SelfGoverning Trade Union "Solidarity" (NSZZ "Solidarność"). In 1982, acting as MP of the 8th term of Sejm (the lower house of parliament in Poland) she was against the delegalization of "Solidarity" as well as an act introducing martial law in Poland. After having been suspended as SD (Democratic Party) member 5 in 1984, she stepped out from the party and focused on her scientific career in the Centre of Human Rights at the Institute of Country and Law of PAN (the Polish Academy of Sciences) in Poznan, where she worked until July, 1992. In 1989 she became an MP representing the Civic Committee ${ }^{6}$. She became the deputy chairperson of the Legislative Commission and presided over parliamentary teams responsible for human rights in the Constitutional Commission. In 1991 she joined UD (Democratic Union) which she also represented in the Polish Parliament. In 1992 she was the head of a group of Polish MPs representing Poland at the Parliamentary Gathering of the Council of Europe in Strasbourg. Between May and October, 1992, she served as the body's deputy chairperson. For her efforts geared towards integration and human rights she

\footnotetext{
${ }^{3}$ A list of women responsible for Polish economy in the Council of Ministers between 1989 and 2008 was shown in Table 1.

${ }^{4}$ Hanna Suchocka, Smolecki serwis informacyjny, http://smolec.com/kobiety/hannasuchocka.htm,12.03.2008.

5 “Gazeta Wyborcza”, 4-5.07.1992.

6 "Gazeta Wyborcza”, 30.10.1997.
} 
was awarded a Golden Medal of Jean Monnet's Foundation. After Jan Olszewski stepped down as the PM, she became the PM of a coalition government formed by seven (and later eight) political parties. While Hanna Suchocka was in power, Poland recorded its first economic growth owing to the economic reforms introduced by Leszek Balcerowicz. Hanna Suchocka's government managed to maintain budget's discipline, brought down inflation and signed "A Package about a company" a deal negotiated with trade unions ${ }^{7}$. Her government also prepared a project of administrative and constitutional reform. The investment level was on the increase and the tariffs were amended. Since July, 1993, investors active in regions facing high unemployment have been given tax incentives. Nevertheless, poor communication with society, the rising social unrest as well as the government's lack of concern about old age pensioners and people on sickness benefit led to a vote of no confidence demanded by the Parliamentary Commission of "Solidarity" as a result of which Hanna Suchocka had to step down'. In Jerzy Buzek's government Hanna Suchocka became the Minister of Justice. In November, 2000, she joined the Council of Women World Leaders, an organization aiming at "encouraging young women to strive for leading positions in their governments". In December, 2001, she became Poland's ambassador at the Holy See.

2. The Deputy Prime Minister. The position was held by Zyta Gilowska who joined UW (Freedom Union) in 1994. She remained without any political affiliations between 1997 and 2001. In 2001 she became a member of PO (Civic Platform) and later a member of PiS (Law and Justice) ${ }^{9}$. At the same time she was in charge of the financial ministry in both K.Marcinkiewicz's ${ }^{10}$ and J.Kaczyński's governments. In June 2006, she was recalled as both the deputy PM and the Minister of Finance because she was suspected of submitting a false vetting statement. The Spokesman of Public Interest Włodzimierz Olszewski accused Hanna Suchocka that she lied when she said that she did not collaborate with the Polish People's Republic secret police. In September, 2006, the Vetting Court passed a verdict that Zyta Gilowska did not lie in her vetting statement. In September 2006, she was again appointed the Minister of Finance and the deputy PM. She opted for Poland's budget deficit not higher than 30 billion PLN. She also advocated the need for lowering the level of unemployment and the necessity of introducing a reform of public finances.

\footnotetext{
7 Hanna Suchocka, op.cit.

8 Ibidem.

9 A. Małkiewicz, Rząd Marcinkiewicza, Wrocław 2006, p. 135.

${ }^{10}$ Rządy koalicyjne w III RP, M. Chmaj (ed), Olsztyn 2006, p. 279.
} 
3. The Minister of Spatial Development and Civil Engineering - a position which was held by Barbara Blida. Between 1977 and 1993 she worked as the main specialist in the development section of Coal Mining Building Company "Fabud" in Siemianowice Śląskie. Between 1969 and 1990 she was a member of PZPR (Polish United Labour Party), then she joined SdPR (Social Democracy of the Republic of Poland) and finally, in 1999, she became a member of SLD (Democratic Left Alliance). She became a member of the party's national committee while she was one of Silesian leaders of the party. Eventually, she became the party's deputy chairperson"1. In 1989 she became a deputy in the Polish Sejm ${ }^{12}$, where her mandate ran until 2005. From 1993 to $1996^{13}$ she was the Minister of Spatial Development and Civil Engineering in the successive governments of Waldemar Pawlak, Józef Oleksy and Włodzimierz Cimoszewicz. In 1994 she was appointed the government's plenipotentiary for women affairs ${ }^{14}$. However, during her term in office she did not manage to introduce a housing industry reform which was supposed to include rents' aids to the poor. The Budget Commission decided to relocate 1.25 billion PLN from Mrs Blida's section to another department responsible for employment ${ }^{15}$. In 1997 she was nominated as the chairwoman of the Office of Housing and Cities' Development and in 2001 she became the board's president of a property developer J.W. Construction. On 25th April, 2007, during a house search carried out by ABW (the Internal Security Agency) which was a part of an investigation into the coal mafia case, Barbara Blida shot herself and died as a result.

4. The Minister of Finance. Between 1989 and 2008 three women were in charge of this ministry. Those included Zyta Gilowska (who at the same time held the position of a deputy PM), Teresa Lubińska and Halina Wasilewska-Trenkner.

Teresa Lubińska was a UW (Freedom Union) member until 2002 ${ }^{16}$. Now she is politically non-aligned. In both 2002 and 2206 she ran for the position of the mayor of Szczecin - without much success. At the same time, she also ran as a candidate for the city's council ${ }^{17}$. The mandate of a councillor she obtained in 2002 as well as four years later. In K.Marcinkiewicz's government she was in charge of the Ministry

11 Who is Who w Polsce. Encyklopedia biograficzna z życiorysami znanych Polek i Polaków, Schweiz 2003, p. 281.

12 M. Czajka, M. Kamler, W. Sienkiewicz, Leksykon Historii Polski, Warszawa 1995, p. 55.

13 W. Jednaka, Gabinety koalicyjne w III RP. Wrocław 2004, p. 231-240.

14 "Gazeta Wyborcza”, 15.12.1994.

15 “Gazeta Wyborcza”, 17.02.1994.

${ }_{16}$ M. Kamola-Cieślik, Aspekt ekonomiczny w programach wyborczych kandydatów na Urząd Prezydenta Miasta Szczecin w 2006 roku, "Przegląd Zachodniopomorski” 2008, vol. 1, p. 8-13.

17 Ibidem. 
of Finance. While serving as the Minister of Finance she had a different view than the PM K.Marcinkiewicz on the country's budget's deficit. She was of the opinion that the deficit should be increased in 2006 by 1 billion PLN up to a total of 31 billion PLN.

The budget surplus was supposed to be spent on research into the high-tech sector ${ }^{18}$. She was also against building new hypermarkets, as they posed a threat to small local shops and that they were not conducive to the development of productive investment.

In 1986, H. Wasilewska-Trenkner ${ }^{19}$ was a deputy head of the People's Employment and Income Section in the Planning Commission of the Council of Ministers (KPRM). The following year she was appointed the position of a deputy director of a Section of Regulation Systems and Planning Methods. She held the position until the moment of KPRM's dissolution ${ }^{20}$. In 1989, she became a director of Economic System Department at CUP (the Central Planning Office) and two years later she was nominated a director of Economic Strategy Department of CUP (the Central Planning Office). In 1991, H. Wasilewska-Trenkner worked as the secretary of state at CUP. Between 1995 and 2001, while acting as an undersecretary of state in the Ministry of Finance she was responsible for the preparation and implementation of the country's budget ${ }^{21}$. In Jerzy Buzek's government she was the Minister of Finance ${ }^{22}$ for a period of mere two months.

5. The Minister of Industry and Trade. In 1991, Henryka Bochniarz was appointed by the PM Jan Krzysztof Bielecki the Minister of Industry and Trade ${ }^{23}$. While holding the position, she commissioned ARP (the Industry Development Agency) to lodge a tender in order to select a company that would develop a Programme of Restructuring of the Armaments Industry ${ }^{24}$. As a result, a Cracow consulting agency Proxy prepared a report which was accepted by the Defense Industry Council of the Council of Ministers on 6th December, 199125. NIK, i.e. the Supreme Chamber of Control determined that Proxy company whose owner was Marek Dochnal while preparing the Programme of Restructuring of the Armaments Industry was using secret materials which the Ministry of Defense did not agree to be accessed.

18 J. Solska, Minister Lubińska, "Polityka" 2005, No. 46, p. 32.

19 A List of 2000 People Holding Power in Poland, Warszawa 1994, p. 112

20 Ibidem.

${ }^{21}$ Ibidem.

22 http://www.kprm.gov.pl

${ }^{23}$ K. Leszczyńska, Rządy Rzeczypospolitej Polskiej w latach 1989-2001. Skład, organizacja i tryb funkcjonowania, Toruń 2005, s. 335.

24 “Gazeta Wyborcza”, 26.01.1993; “Rzeczpospolita”, 16.06.2005.

25 “Gazeta Wyborcza”, 26.01.1993 and 8.10.1991. 
In her opinion, the consulting agency's report was worthless and her fee (amounting to over 4 billion PLN) for implementing the programme was much too high. The prosecutor's chargers in this case were quashed.

In 1990, H.Bochniarz founded one of the first consulting agencies - Nicom Consulting Ltd. and Association of Economic Consultants (SDG) in Poland. Between 1996 and 1999 she was the chairperson of Polish Business Council and then she became the president of the Polish Confederation of Private Employers Lewiatan. She returned to politics in 2005 when she decided to run as a candidate in Poland's presidential election while being supported by PD (Democratic Party) although she was not a member of the party. She gained $1.26 \%$ of the votes.

6. The Minister of Regional Development. There were two women who held these positions; Elżbieta Bieńkowska and Grażyna Gęsicka.

Between 1999 and 2007 E.Bieńkowska held the post of a director of Regional Development Section in the Marshall's Office of Silesian province ${ }^{26}$. She was responsible for the planning and implementation of the instruments of regional development financed with the pre-accession funds from EU and the structural funds within the framework of the National Development Plan 2004-200627. E.Bieńkowska became the Minister of Regional Development in D.Tusk's government. She tried to make use of all the funds (approximately 60 billion Euros) allocated to Poland in EU budget for $2007-2013^{28}$. At the same time she decided to change the list of beneficiaries who were supposed to receive EU subsidies without tender procedure ${ }^{29}$ as a result of which the prospective investment projects were reduced ${ }^{30}$. The reserved funds from the list of key projects (from 9.5 to 15 billion Euros) were reallocated to investment projects selected in open competition.

Between 2001 and 2005 G. Gęsicka was the chairperson of Polish Agency for Enterprise Development ${ }^{31}$. In K.Marcinkiewicz and J.Kaczyński’s governments she held the position of the Minister of Regional Development ${ }^{32}$. G. Gęsicka was twice appointed to the position in J.Kaczyński's cabinet. On 7th Sept, 2007, she was recalled by the PM. J.Kaczyński wanted to avoid a planned session of the parliament and a Civic Platform motion of a vote of no confidence against her. Four days later the PM nominated her again as the Minister of Regional Development. While acting as

\footnotetext{
26 Ibidem.

27 “Gazeta Wyborcza”, 14.11.2007 and 16 i 24 I 2008.

28 “Gazeta Wyborcza”, 9.02.2008.

29 "Gazeta Wyborcza", 19.12.2007.

30 "Gazeta Prawna", 1-3.02.2008.

31 A. Małkiewicz, Rzad..., p. 134.

32 Ibidem.
} 
the minister, she managed to increase the level of absorption of EU funds, simplify procedures of applying for development funds and the methods they were accounted for. She also created an efficient system of managing programmes and her efforts focused on decentralizing the management of developmental funds ${ }^{33}$. At the same time she supervised efforts on developing projects of both National Development Strategy 2007-2015 ${ }^{34}$ and National Cohesion Strategy 2007-2013. In 2007 she became a deputy in Polish Parliament as a member of Law and Justice party.

7. The Minister of State Treasury. In J.Buzek's government, Aldona KamelaSowińska ${ }^{35}$ held the position of the Minister of State Treasury. She was responsible for privatizing the armaments industry and strategic companies of the State Treasury. Then she was nominated the Minister of State Treasury. In 2001, she and Eureko company signed an appendix to the contract of privatising PZU (Poland's largest insurance company). According to the agreement the State Treasury sold Eureko $21 \%$ of PZU shares (before the contract was signed Eureko owned - together with BIG BG - 30\% of PZU shares) ${ }^{36}$. In 2002, A. Kamela - Sowińska ran - without success - for the position of the mayor of Poznan. In the following year, she founded and became the leader of a new party - Initiative for Poland ${ }^{37}$ which was dissolved in 2006. A. Kamela - Sowińska has been the first woman ever to serve as the Minister of State Treasury.

Since 1989 thirteen Prime Ministers have been the heads of successive Polish governments. In the Council of Ministers women have held various positions including the posts of PM, deputy PM and ministers. The only exception was J. Olszewski's government in which there were no women.

The total number of nominations of women to these positions in all Polish governments from T. Mazowiecki to D. Tusk's cabinets amounts to 24. However, only 8 women were the heads of ministries responsible for economic matters. At the same time, Hanna Suchocka affected the way Polish economy developed between 1992 and 1993 when she served as Poland's Prime Minister. Several years later she became the Minister of Justice in J. Buzek's cabinet. Between 1989 and 2008 women most frequently were the heads of the Ministry of Finance (Z. Gilowska, T. Lubińska and H. Wasilewska-Trenkner). Additionally, Z. Gilowska held the position of a deputy PM. On the other hand, B. Blida was appointed minister no fewer than three times. Between 1993 and 1997 she was the Minister of Spatial Development and the Min-

33 “Gazeta Wyborcza”, 21.11.2007.

${ }^{34}$ Ibidem.

${ }_{35}$ A List of 2000 People..., p. 125; M. Janicki, Pierwsza księgowa, "Polityka" 2001, No. 16, s. 20.

36 “Gazeta Wyborcza”, 26.09.2001, 5.10.2001, 5.01.2005.

37 http://kamela-sowinska.org.pl 
ister of Civil Engineering. Conversely, A. Kamela - Sowińska was the first woman to be the head of a ministry which previously had been run only by men - i.e. the Ministry of State Treasury.

All the women who were members of the Council of Ministers between 1989 and 2008 and who affected the course of Polish economy in those years had higher education, and some of them had a scientific degree.

Summing up the role of women in successive Polish governments since 1989, it can be said that as far as qualifications and dedication to work go, they in no way can be considered inferior to men, although women often had to combine the roles of politicians and mothers. Moreover, it can also be assumed that it is due to maternal duties that the representation of women in political life is smaller than that of men.

Table 1: A list of women responsible for Polish economy in the Council of Ministers between 1989 and 2008

\begin{tabular}{|c|c|c|c|}
\hline $\begin{array}{l}\text { Name and } \\
\text { Surname }\end{array}$ & $\begin{array}{c}\text { Education } \\
\text { Scientific degree }\end{array}$ & $\begin{array}{l}\text { Position held in } \\
\text { Council of Ministers }\end{array}$ & Period while in office \\
\hline $\begin{array}{l}\text { Elżbieta } \\
\text { Bieńkowska }\end{array}$ & higher & $\begin{array}{l}\text { the Minister of Regional } \\
\text { Development }\end{array}$ & 16th Nov, 2007 \\
\hline $\begin{array}{l}\text { Barbara } \\
\text { Blida }\end{array}$ & higher & $\begin{array}{l}\text { the Minister of Spatial } \\
\text { Development and Civil } \\
\text { Engineering }\end{array}$ & $\begin{array}{l}\text { 26th Oct, 1993-6th March, } \\
1995 \\
\text { 7th March, 1995-26th Jan, } 1996 \\
\text { 7th Feb, 1996-31st Oct, } 1997\end{array}$ \\
\hline $\begin{array}{l}\text { Henryka } \\
\text { Bochniarz }\end{array}$ & $\begin{array}{l}\text { higher, } \\
\text { PhD in economics }\end{array}$ & $\begin{array}{l}\text { the Minister of Industry } \\
\text { and Trade }\end{array}$ & 31st Aug - 5th Dec, 1991 \\
\hline $\begin{array}{l}\text { Grażyna } \\
\text { Gęsicka }\end{array}$ & $\begin{array}{l}\text { higher } \\
\text { PhD in sociology }\end{array}$ & $\begin{array}{l}\text { the Minister of Regional } \\
\text { Development }\end{array}$ & $\begin{array}{l}\text { 31st Oct, 2005-14th July, } 2006 \\
\text { 14th July, 2006-7th Nov, } 2007 \\
\text { 11th Sept, 2007-16th Nov, } 2007\end{array}$ \\
\hline $\begin{array}{l}\text { Zyta } \\
\text { Gilowska }\end{array}$ & $\begin{array}{l}\text { higher } \\
\text { Professor of econo- } \\
\text { mics }\end{array}$ & $\begin{array}{l}\text { deputy PM } \\
\text { the Minister of Finance }\end{array}$ & $\begin{array}{l}\text { 7th Jan, 2006-24th June, } 2006 \\
\text { 22nd Sept, 2006-7th Sept, } 2007 \\
\text { 10th Sept - 16th Nov, } 2007\end{array}$ \\
\hline $\begin{array}{l}\text { Aldona } \\
\text { Kamela- } \\
\text {-Sowińska }\end{array}$ & $\begin{array}{l}\text { higher } \\
\text { Professor of econo- } \\
\text { mics }\end{array}$ & $\begin{array}{l}\text { the Minister of Owner- } \\
\text { ship Transformation }\end{array}$ & 28th Feb - 19th Oct, 2001 \\
\hline $\begin{array}{l}\text { Teresa } \\
\text { Lubińska }\end{array}$ & $\begin{array}{l}\text { higher } \\
\text { PhD and habilita- } \\
\text { tion in economics } \\
\text { (Professor of Uni- } \\
\text { versity of Szczecin) }\end{array}$ & the Minister of Finance & 31st Oct, 2005-7th Jan, 2006 \\
\hline
\end{tabular}




\begin{tabular}{|l|l|l|l|}
\hline $\begin{array}{l}\text { Name and } \\
\text { Surname }\end{array}$ & \multicolumn{1}{|c|}{$\begin{array}{c}\text { Education } \\
\text { Scientific degree }\end{array}$} & $\begin{array}{c}\text { Position held in } \\
\text { Council of Ministers }\end{array}$ & Period while in office \\
\hline $\begin{array}{l}\text { Hanna } \\
\text { Suchocka }\end{array}$ & $\begin{array}{l}\text { higher } \\
\text { PhD in constitutio- } \\
\text { nal law }\end{array}$ & PM & 11th July, 1992-25th Dec, 1993 \\
\hline $\begin{array}{l}\text { Halina } \\
\text { Wasilewska- } \\
\text {-Trenkner }\end{array}$ & $\begin{array}{l}\text { higher } \\
\text { PhD in economics }\end{array}$ & the Minister of Finance & 28th Aug - 19th Oct, 2001 \\
\hline
\end{tabular}

The list has been compiled by the author of the present publication on the basis of: Rzady koalicyjne w III RP. ed. M. Chmaj, Olsztyn 2006; K. Leszczyńska, Rzady Rzeczypospolitej Polskiej w latach 1989-2001. Skład, organizacja i tryb funkcjonowania, Torun 2005; Wykaz 2000 osób sprawujących władzę w Rzeczypospolitej Polskiej. Warszawa 1998. 